\title{
SP011 Gene
}

National Cancer Institute

\section{Source}

National Cancer Institute. SPO11 Gene. NCI Thesaurus. Code C21406.

This gene plays a role in meiotic recombination and centromere association. 